\title{
Representasi Visual Dalam Menyelesaikan Masalah Pecahan
}

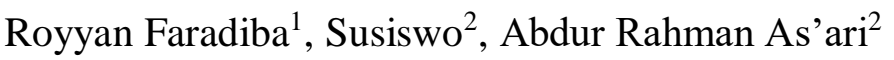 \\ ${ }^{1}$ Pendidikan Dasar-Universitas Negeri Malang \\ ${ }^{2}$ Pendidikan Matematika-Universitas Negeri Malang
}

\begin{tabular}{l}
\hline INFO ARTIKEL \\
\hline Riwayat Artikel: \\
Diterima: 06-02-2019 \\
Disetujui: 19-07-2019 \\
\hline
\end{tabular}

\section{Kata kunci:}

visual representation; fraction;

solution to problem; representasi visual; pecahan;

pemecahan masalah

\begin{abstract}
ABSTRAK
Abstract: This study aims to describe the visual representation of grade 5 students in elementary schools in solving fraction problems. The research method used is descriptive qualitative. Data is collected through interviews, recording and student work. The research subjects were 3 students namely those who had high, medium and low mathematical abilities based on the results of the last report card. The results showed that there was no relationship between students 'mathematical abilities and students' visual representation. Students with high mathematical abilities can accurately represent the concept of fractions in the form of a picture but cannot represent the concept of fraction multiplication and compare two fraction numbers into the exact image. Students with moderate and low mathematical abilities cannot represent fraction concepts and multiplication concepts and compare two fraction numbers into image shapes correctly. Based on the results of this study it is expected that the teachers will provide a deeper understanding of the use of visual representation in fraction learning.
\end{abstract}

\begin{abstract}
Abstrak: Penelitian ini bertujuan untuk mendeskripsikan representasi visual siswa kelas $\mathrm{V}$ sekolah dasar dalam menyelesaikan masalah pecahan. Metode penelitian yang digunakan adalah kualitatif deskriptif. Data dikumpukan melalui wawancara, perekaman dan pekerjaan siswa. Subjek penelitian berjumlah tiga siswa, yaitu siswa yang memiliki kemampuan matematika tinggi, sedang, dan rendah berdasarkan hasil rapor terakhir. Hasil penelitian menunjukkan bahwa tidak ada hubungan antara kemampuan matematika siswa dengan representasi visual siswa. Siswa berkemampuan matematika tinggi dapat merepresentasikan konsep pecahan ke dalam bentuk gambar dengan tepat, tetapi tidak dapat merepresentasikan konsep perkalian pecahan dan membandingkan dua bilangan pecahan ke dalam bentuk gambar dengan tepat. Siswa berkemampuan matematika sedang dan rendah tidak dapat merepresentasikan konsep pecahan, dan konsep perkalian serta membandingkan dua bilangan pecahan ke dalam bentuk gambar dengan tepat. Berdasarkan hasil penelitian ini diharapkan bagi para guru untuk memberikan pemahaman yang lebih dalam tentang penggunaan representasi visual dalam pembelajaran pecahan.
\end{abstract}

\author{
Alamat Korespondensi: \\ Royyan Faradiba \\ Pendidikan Dasar \\ Universitas Negeri Malang \\ Jalan Semarang 5 Malang \\ E-mail: royyanfaradiba22@gmail.com
}

Salah satu dari lima standar proses adalah representasi (NCTM, 2000). Standar representasi memungkinkan siswa untuk membuat dan menggunakan representasi untuk mengatur, merekam, dan mengomunikasikan ide-ide matematika. Huinker (2015) menjelaskan bahwa representasi dapat diekspresikan dalam bentuk visual, verbal, dan simbolis. Representasi visual termasuk mengilustrasikan, menunjukkan, atau bekerja dengan ide-ide matematika menggunakan diagram, gambar, garis bilangan, grafik, dan gambar matematika lainnya. Representasi verbal termasuk menggunakan bahasa (kata dan frasa) untuk menafsirkan, mendiskusikan, mendefinisikan atau menggambarkan ide-ide matematika, menjembatani bahasa matematika informal dan formal. Representasi simbolis termasuk merekam atau bekerja dengan ide-ide matematika menggunakan angka, variabel, tabel, dan simbol lainnya. Selanjutnya Minarni dan Napitupulu (2016) mengatakan representasi dapat disajikan oleh siswa dalam bentuk figur, grafik, tabel, persamaan (model matematika), penjelasan dalam kata-kata atau kalimat. Representasi diketahui berguna untuk mewakili ide matematika sehingga orang lain paham akan maksud dan maknanya (NCTM, 2000).

Salah satu representasi matematis yang dilakukan dalam menyelesaikan suatu masalah adalah menggunakan model visual. Menurut (Özkan, Arikan, \& Özkan, 2018) mengatakan bahwa model visual memiliki kemampuan untuk membantu siswa dalam memahami masalah. (Ainsworth \& VanLabeke, 2004) mengatakan model visual seperti diagram dan gambar, merupakan 
alat yang kuat dalam pembelajaran matematika dan pemecahan masalah. Kemudian, (Ahmad, Tarmizi, \& Nawawi, 2010) mengatakan bahwa model visual dalam masalah matematika dapat memudahkan anak dalam membuat rencana penyelesaian. Dengan demikian, menggunakan model visual menjadi cara yang efektif untuk mendukung pemahaman masalah dan pemecahannya (van Garderen \& Montague, 2003). Cramer (2008) juga mengungkapkan bahwa mengubah masalah matematika ke dalam bentuk visual akan membuat gagasan lebih bermakna bagi siswa. Selanjutnya, representasi visual sangat dibutuhkan dalam memecahkan masalah matematika (Stylianou, 2011). Oleh karena itu, model visual sudah seharusnya dikuasai oleh siswa karena sangat diperlukan dalam pembelajaran matematika. Selanjutnya, model visual juga merupakan bentuk representasi yang penting dan diperlukan untuk mendukung pemahaman dan pemecahan masalah matematika.

Untuk melihat kemampuan representasi visual siswa dalam menyelesaikan masalah pecahan, peneliti memberikan sebuah masalah kepada siswa. Adapun masalah yang diberikan adalah seutas tali dipotong $\frac{1}{3}$ nya dan sisanya dipotong lagi $\frac{3}{4}$ nya. Tali itu sekarang tinggal $20 \mathrm{~cm}$. Berapa meter panjang tali semula?. Soal tersebut merupakan soal pemecahan masalah pada pecahan. Dalam menyelesaikan soal, siswa dengan inisial ST menggunakan representasi visual. Berikut ini jawaban ST menggunakan representasi visual yang ditunjukkan pada gambar 1.

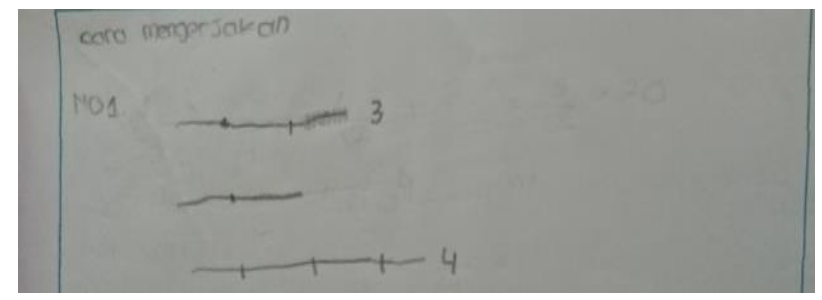

Gambar 1. Jawaban Siswa

Berdasarkan hasil yang telah diselesaikan oleh siswa tersebut, ST menggambarkan tali yang dipotong menjadi 3 bagian. Kemudian ketika memotong $\frac{1}{3}$ dari tali tersebut, ST dapat melakukannya yaitu dengan mengarsir bagian dari $\frac{1}{3}$ tersebut. Arsiran $\frac{1}{3}$ bagian ini merupakan bagian tali yang dipotong mula-mula. Selanjutnya, ketika memotong sisa tali menjadi $\frac{3}{4}$ dari sisanya, siswa tersebut tidak dapat melakukannya, ST hanya menggambarkan tali yang dibagi menjadi empat bagian sehingga masing-masing sebanyak $\frac{1}{4}$ bagian. Berdasarkan hasil pekerjaan ST, diketahui bahwa ST mengalami kesulitan dalam menggunakan model visual dalam menyelesaikan masalah tersebut. Dalam penelitiannya, Eleni (2009) mengatakan bahwa mengubah masalah ke dalam bentuk visual diperlukan dalam pembelajaran matematika dan pemecahan masalah.

Ada beberapa penelitian yang terkait dengan representasi visual siswa. Lamberg \& Wiest (2014) mengatakan bahwa kesulitan terbesar yang dialami siswa dalam pembelajaran pecahan adalah merepresentasikan masalah pembagian ke bentuk visual. Selain itu, Raiyn (2016) menyatakan bahwa sebagian besar siswa tidak benar-benar memahami pentingnya penggunaan model visual dalam menyelesaikan masalah matematika sehingga ketika menyelesaikan masalah para siswa melakukan kesalahan dalam menyelesaikan masalah tersebut. Selanjutnya, (Mustafa \& Cuneyt, 2016) mengatakan terdapat kesalahan dalam menggunakan model visual, yaitu (1) siswa membuat kesalahan secara langsung yaitu tidak menggunakan visual dalam menyelesaikan masalah, (2) siswa membuat gambar tidak benar karena kurangnya pengetahuan mengenai matematika dalam kehidupan nyata, (3) siswa membuat gambar dengan benar, tetapi salah ketika menafsirkannya, (4) siswa membuat gambar tidak lengkap, (5) siswa membuat ilustrasi yang salah pada masalah yang diberikan, dan (6) siswa membuat gambar dengan benar tetapi tidak dapat mengomunikasikannya. Beberapa penelitian di atas menunjukkan kesalahan dan kesulitan yang dilakukan siswa dalam menyelesaikan masalah pecahan menggunakan model visual. Sampai sejauh ini belum ada teori yang menjelaskan tentang hubungan kemampuan matematika dengan representasi visual. Oleh karena itu, penelitian ini dilakukan untuk mendeskripsikan representasi visual siswa yang terkait dengan kemampuan matematika siswa dalam menyelesaikan masalah pecahan. Selanjutnya, penelitian ini juga menggambarkan bahwa representasi visual diperlukan bagi seluruh siswa. Pemahaman mengenai representasi visual sudah seharusnya menjadi salah satu cara dalam menyelesaikan masalah matematika. Oleh karena itu, sebagai seorang guru tentunya harus berusaha untuk memaksimalkan penggunaan representasi visual agar siswa dapat memahami penggunaannya dalam menyelesaikan masalah dengan baik.

\section{METODE}

Penelitian ini menggunakan metode kualitatif deskriptif. Penelitian ini bertujuan untuk mendeskripsikan representasi visual siswa SD dalam menyelesaikan masalah pecahan. Subjek penelitian diambil dari siswa kelas V SD yang telah mengenal konsep pecahan dan pengoperasiannya. Metode yang digunakan pada penelitian ini adalah observasi, wawancara, dan dokumentasi berupa foto. Fokus representasi yang digunakan pada penelitian ini adalah representasi eksternal khususnya representasi visual. Penelitian ini dilakukan pada hari Senin, 09 April 2018. Peneliti memberikan sebuah masalah kepada seluruh siswa. Setelah itu, peneliti mengelompokkan berdasarkan kemampuan matematika siswa yang dilihat dari nilai rapor terakhir. 
Dari ketiga kelompok tersebut, diambil satu orang dari masing-masing kelompok yaitu siswa yang mempunyai kemampuan matematika tinggi, sedang, dan rendah. Ketiga siswa tersebut di antaranya S1, S2, dan S3 dijadikan subjek dalam penelitian ini. Pengelompokan ini bertujuan untuk mengetahui representasi visual pada siswa yang berkemampuan matematika tinggi, sedang, dan rendah. Karakteristik representasi matematis yang muncul adalah representasi visual yang diwujudkan dalam bentuk gambar pada masalah yang diberikan

Setelah mendapatkan subjek penelitian, peneliti memberikan masalah kepada subjek. Setelah pengerjaan selesai, peneliti melakukan wawancara terkait dengan jawaban atas masalah yang diberikan. Masalah tersebut diantaranya, siti mempunyai satu pizza, kemudian Ani mengambil $\frac{2}{6}$ bagiannya, dan Mina mengambil $\frac{4}{8}$ bagiannya. Sebelum dimakan, $\frac{1}{6}$ bagian milik Mina terjatuh. Siapa yang memakan lebih banyak antara Ani dan Mina? Buatlah ilustrasi gambarnya. Ketika hasil tes dan hasil wawancara sudah didapatkan, peneliti menganalisis data, mereduksi data, dan menyajikan data. Analisis pekerjaan siswa dilakukan berdasarkan indikator-indikator tabel 1 .

Tabel 1. Indikator Representasi Visual

\begin{tabular}{cll}
\hline No. & \multicolumn{1}{c}{ Indikator } & \multicolumn{1}{c}{ Deskripsi } \\
\hline 1 & Siswa dapat merepresentasikan konsep pecahan ke & Merepresentasikan gambar yang mewakili nilai dari masing-masing \\
dalam bentuk gambar & pecahan
\end{tabular}

\section{HASIL}

Penjelasan berikut adalah hasil yang diperoleh oleh tiga subjek yaitu siswa yang berkemampuan matematika tinggi, sedang dan rendah. Subjek Penelitian disajikan pada tabel 2 dan representasi visual siswa kelas V dalam menyelesaikan masalah pecahan dapat dilihat pada tabel 3 .

Tabel 2. Subjek Penelitian dan Kategorinya

\begin{tabular}{ccc}
\hline No & Nama Peserta Didik & Kategori \\
\hline 1 & S1 & Tinggi \\
\hline 2 & S2 & Sedang \\
\hline 3 & S2 & Rendah \\
\hline
\end{tabular}

Tabel 3. Representasi Visual Siswa

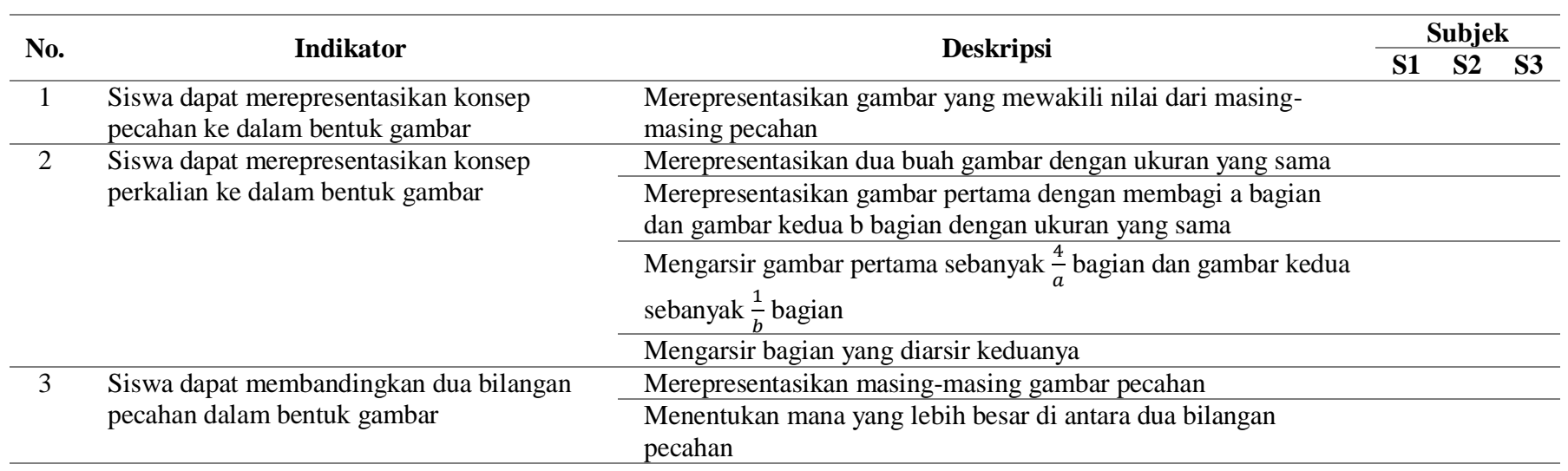




\section{Representasi Visual Siswa Berkemampuan Matematika Tinggi (S1) dalam Menyelesaikan Masalah}

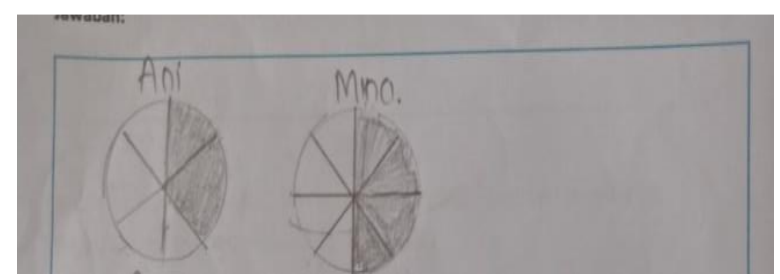

\section{Gambar 2. Hasil Jawaban S1}

Berdasarkan hasil pekerjaan S1, dapat dilihat bahwa S1 dapat merepresentasikan gambar yang mewakili nilai dari pecahan $\frac{2}{6}$ dan $\frac{4}{8}$. Namun, ketika $\frac{1}{6}$ bagian milik mina terjatuh, S1 tidak dapat merepresentasikannya. Ini artinya S1 tidak dapat merepesentasikan konsep perkalian menggunakan gambar. Selanjutnya ketika menentukan bagian mana yang lebih besar antara pizza Ani dan Mina, S1 tidak dapat melakukannya karena S1 tidak dapat merepresentasikan konsep perkalian pada langkah sebelumnya. Berikut hasil wawancara peneliti dengan S1 yang ditunjukkan pada gambar 3.

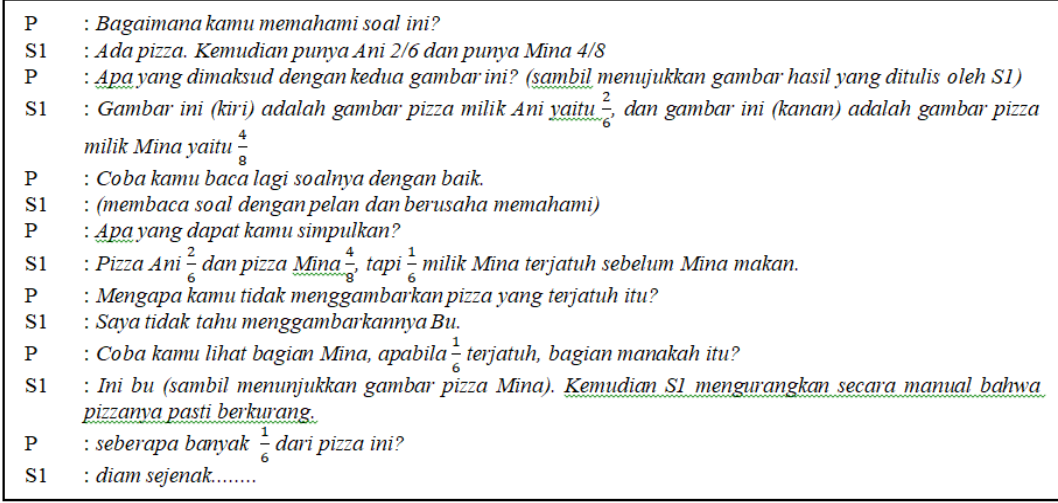

Gambar 3. Dialog 1 Subjek 1

Representasi Visual Siswa Berkemampuan Matematika Sedang (S2) dalam Menyelesaikan Masalah

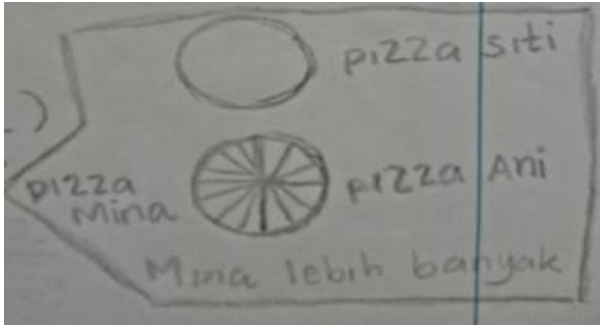

Gambar 4. Hasil Jawaban S2

Berdasarkan hasil pekerjaan S2, S2 tidak dapat merepresentasikan gambar yang mewakili nilai dari pecahan $\frac{2}{6}$ dan $\frac{4}{8} . \mathrm{S} 2$ hanya mengidentifikasi masalahnya dengan membuat gambar yang mewakili sebuah pizza kemudian membagi pizza menjadi 2 bagian yang sama. Selanjutnya, dalam merepresentasikan perkalian pecahan menggunakan gambar, S2 tidak dapat merepresentasikannya karena S2 tidak dapat merepresentasikan konsep pecahan pada langkah sebelumnya. Sehingga jika siswa tidak dapat merepresentasikan langkah sebelumnya, maka akan berdampak pada representasi lain yang dibuatnya. Selanjutnya, dalam menentukan bagian mana yang lebih besar antara pizza Ani dan Mina, S2 tidak dapat melakukannya. S2 hanya membagi bagian kiri menjadi enam yang menunjukkan bagian Ani dan membagi bagian kiri menjadi delapan bagian yang menunjukkan bagian Mina sehingga bagian Mina lebih banyak dari bagian Ani. Berikut hasil wawancara peneliti dengan S2 yang ditunjukkan pada gambar 5 . 


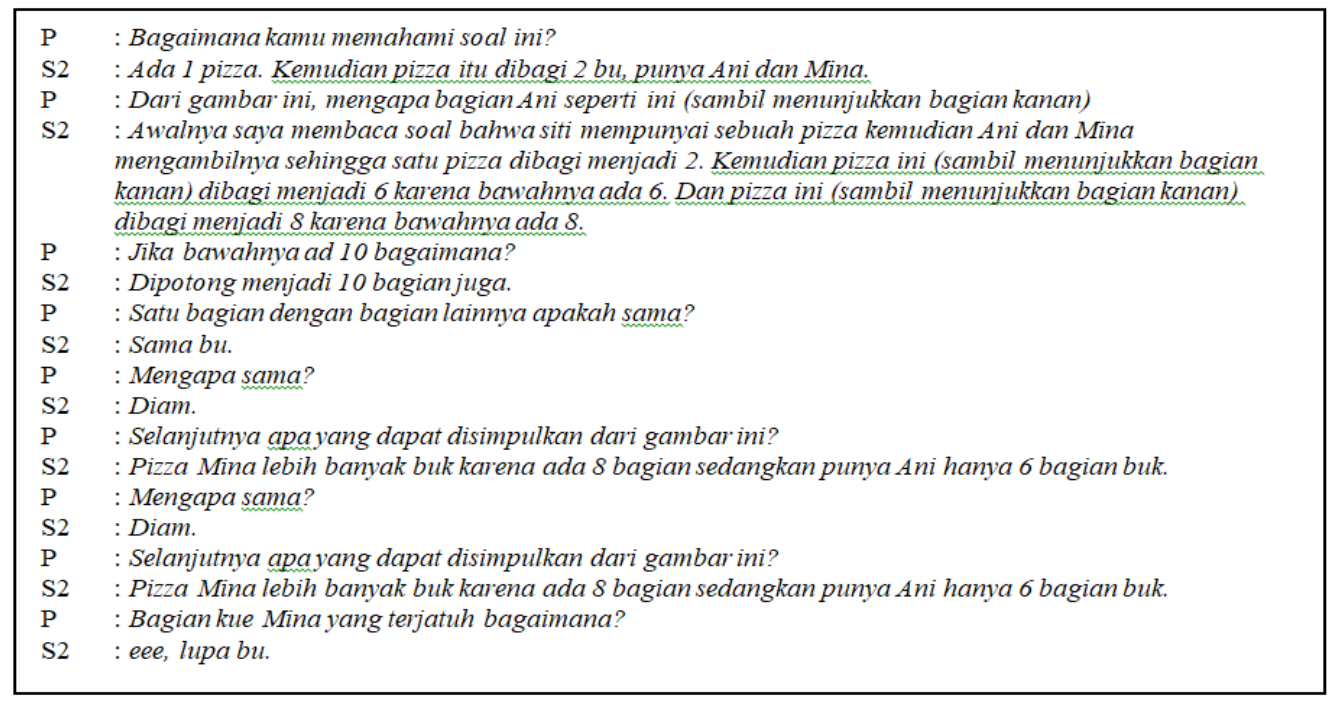

\section{Gambar 5. Dialog 2 Subjek 2}

\section{Representasi Visual pada Siswa yang Berkemampuan Rendah (S3) dalam Menyelesaikan Masalah}

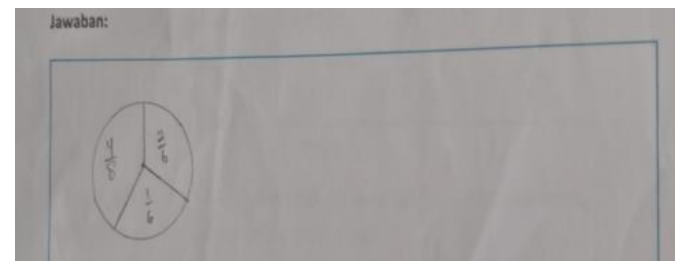

\section{Gambar 6. Hasil Jawaban S3}

Berdasarkan hasil pekerjaan S3, gambar 6 yang berbentuk pizza dengan ukuran yang sama yaitu bagian $\frac{4}{8}, \frac{2}{6}$, dan $\frac{1}{6}$. Ini berarti S3 tidak dapat merepresentasikan konsep pecahan menggunakan gambar yang mewakili $\frac{4}{8}$ dan $\frac{2}{6}$. Selanjutnya dalam menentukan bagian mana yang lebih besar antara pizza Ani dan Mina, S3 tidak dapat merepresentasikannya dikarenakan S2 juga tidak dapat merepresentasikan konsep perkalian pecahan pada langkah sebelumnya. Berikut hasil wawancara S3 yang ditunjukkan pada gambar 7 .

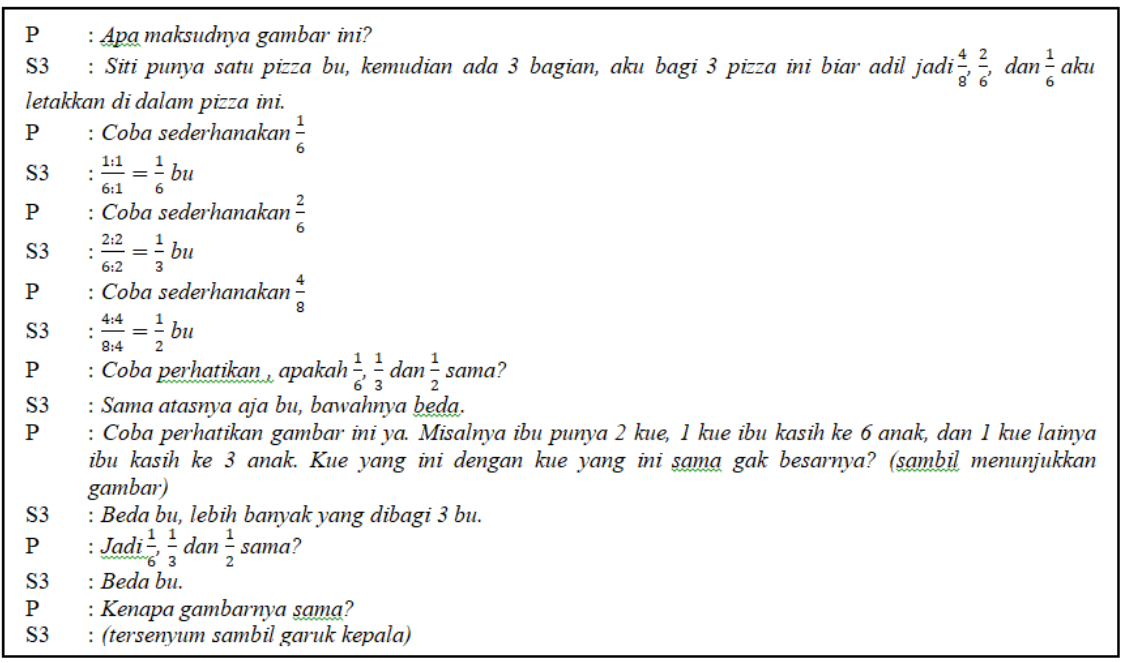

Gambar 7. Dialog 3 


\section{PEMBAHASAN}

S1 dapat merepresentasikan konsep pecahan menggunakan gambar dalam menyelesaikan masalah. Seperti yang diungkapkan oleh Edith (2006) bahwa gambar dapat membantu siswa dalam memahami konsep pada soal-soal pecahan sekolah dasar. Namun, S1 tidak menyelesaikan masalah dengan baik dan belum mampu menemukan solusi dari masalah tersebut. Barake (2015) mengatakan bahwa tidak lengkapnya jawaban yang diperoleh dan hasil yang salah disebabkan karena siswa tidak mengerti cara melanjutkan proses penyelesaiannya dan tidak yakin bahwa rencana tersebut benar. Hal ini menunjukkan bahwa S1 tidak dapat merepresentasikan konsep perkalian dalam soal ini. Booler (2015) mengatakan bahwa hal yang paling sering tidak dapat dilakukan oleh siswa adalah merepresentasikan perkalian pecahan menggunakan gambar. Sebagian besar siswa merepresentasikan perkalian pecahan menggunakan representasi simbolik karena tidak memahami bagaimana merepresentasikan konsep perkalian pecahan menggunakan gambar (Smooth, 2016). Selanjutnya dalam menentukan bagian mana yang lebih besar antara pizza Ani dan Mina, S1 tidak dapat merepresentasikannya. (Ervin, 2017) mengatakan bahwa representasi suatu konsep memengaruhi pembentukan representasi lainnya. Selain itu, Smooth (2009) mengatakan jika setiap siswa dapat menyelesaikan masalah hingga selesai, maka konsep lain yang terdapat dalam masalah itu dapat dikuasai dengan baik.

Subjek yang mempunyai kemampuan matematika sedang (S2) sama sekali tidak dapat merepresentasikan konsep menggunakan gambar pada soal. Gooding (2009) mengatakan bahwa kategori pertama dalam menyelesaikan soal cerita menggunakan model visual adalah pemahaman dalam mengartikan kalimat dalam soal. Ketidakpahaman tersebut menyebabkan siswa tidak dapat melanjutkan penyelesaian masalah yang dihadapi dengan benar. Enward (2005) mengatakan bahwa konsep pecahan merupakan salah satu konsep yang begitu penting dalam pembelajaran, karena jika telah menguasai konsep pecahan, maka konsep lain yang berhubungan dengannya akan lebih mudah dipahami dengan baik dan konsep pecahan akan lebih bermakna jika direpresentasikan secara visual. Selanjutnya, dalam merepresentasikan perkalian pecahan menggunakan gambar, S2 tidak dapat melakukannya karena S2 tidak dapat merepresentasikan konsep pecahan pada langkah sebelumnya. (Ervin, 2017) mengatakan bahwa representasi suatu konsep memengaruhi pembentukan representasi lainnya. Sehingga ketika siswa tidak dapat merepresentasikan sebuah konsep menggunakan gambar pada suatu soal maka akan berdampak pada representasi visual lain yang dibuatnya.

Subjek yang mempunyai kemampuan matematika rendah (S3) juga tidak dapat merepresentasikan pecahan ke dalam bentuk gambar. Enward (2005) mengatakan bahwa konsep pecahan merupakan salah satu konsep yang begitu penting dalam pembelajaran, karena jika telah menguasai konsep pecahan, maka konsep lain yang berhubungan dengannya akan lebih mudah dipahami dengan baik. Selanjutnya, dalam merepresentasikan perkalian pecahan menggunakan gambar, S3 tidak dapat merepresentasikannya karena sebelumnya S1 tidak dapat merepresentasikan konsep pecahan. (Ervin, 2017) mengatakan bahwa representasi suatu konsep dan ide lain memengaruhi pembentukan representasi lainnya. Sehingga ketika S3 tidak dapat merepresentasikan konsep pecahan menggunakan model visual maka akan berdampak pada representasi konsep perkalian pecahan yang dibuatnya. Seperti yang diketahui, menggunakan model visual menjadi cara yang efektif untuk mendukung pemahaman masalah dan pemecahannya (van Garderen \& Montague, 2003). Visual tidak hanya dapat digunakan dalam mempelajari konsep dan keterampilan, tetapi juga dapat digunakan untuk memecahkan masalah. Selanjutnya dalam menentukan bagian mana yang lebih besar antara pizza Ani dan Mina, S3 tidak dapat merepresentasikannya dikarenakan S3 tidak dapat merepresentasikan konsep pecahan dan perkalian pecahan pada langkah sebelumnya.

Gooding (2009) mengatakan bahwa kategori pertama dalam menyelesaikan soal cerita menggunakan model visual adalah pemahaman dalam mengartikan kalimat dalam soal. Ketidakpahaman tersebut menyebabkan siswa tidak dapat melanjutkan penyelesaian masalah yang dihadapi dengan benar. Selain itu, Yilmaz (2018) mengatakan bahwa jika siswa tidak dapat merepresentasikan konsep dapat menyebabkan kesalahan pada tahap-tahap selanjutnya dalam menyelesaikan masalah. Hal ini sejalan dengan Hidayati (2017) yang mengatakan bahwa kesalahan siswa dalam menyusun strategi penyelesaian dengan benar karena ketidaktahuan dalam merepresentasikan konsep matematika.

Dalam penelitian ini menunjukkan bahwa sebagian besar siswa tidak dapat mempresentasikan masalah menggunakan model visual. Kecenderungan siswa selalu memecahkan masalah dalam bentuk simbol yang dianggap telah menyelesaikan masalah (Sukoriyanto, 2016). Penelitian lain juga menyatakan bahwa siswa lebih sering menggunakan simbol daripada model visual dalam menyelesaikan masalah matematika karena simbol lebih mudah direpresentasikan (Hiebert, 2011). Selain itu, minimnya penggunaan model visual di kalangan siswa sekolah dasar disebabkan oleh guru yang kurang memaksimalkan pembelajaran menggunakan model visual. Guru tidak menggunakan model visual dalam pembelajaran dikarenakan sebagian besar guru tidak mengerti penggunaannya (Enwardd 2005).

\section{SIMPULAN}

Berdasarkan hasil penelitian terhadap masalah pecahan di atas, dapat disimpulkan bahwa tidak ada hubungan antara kemampuan matematika siswa dengan representasi visual siswa. Siswa berkemampuan matematika tinggi dapat merepresentasikan konsep pecahan ke dalam bentuk gambar dengan tepat tetapi tidak dapat merepresentasikan konsep perkalian pecahan dan membandingkan dua bilangan pecahan ke dalam bentuk gambar dengan tepat. Siswa berkemampuan matematika sedang dan rendah tidak dapat merepresentasikan konsep pecahan, dan konsep perkalian serta membandingkan dua bilangan pecahan ke dalam bentuk gambar dengan tepat. Dalam hasil yang terlihat pada masing-masing jawaban siswa, dapat dikatakan bahwa pembelajaran yang dilakukan oleh guru adalah pembelajaran yang masih mengedepankan representasi simbolik 
dibandingkan representasi visual. Guru lebih condong menyelesaikan masalah pecahan menggunakan simbolik daripada visual. Selanjutnya, siswa lebih memahami masalah pecahan menggunakan simbolik dibandingkan visual karena visual lebih sulit dibandingkan dengan simbolik. Selain itu, sebagian besar siswa merepresentasikan konsep perkalian pecahan menggunakan representasi simbolik karena tidak memahami bagaimana merepresentasikan konsep tersebut menggunakan gambar. Untuk itu, diharapkan bagi para guru untuk memberikan pemahaman yang lebih dalam tentang penggunaan representasi visual dalam pembelajaran pecahan. Dalam beberapa penelitian, memecahkan masalah menggunakan model visual dapat membuat pemahaman dan pemecahan masalah siswa menjadi lebih baik.

Dalam penelitian ini, peneliti hanya meneliti tiga orang dari masing-masing kelompok yaitu satu siswa yang memiliki kemampuan matematika tinggi, satu siswa yang memiliki kemampuan matematika sedang, dan satu siswa yang memiliki kemampuan matematika rendah. Untuk itu diharapkan penelitian selanjutnya dapat memperoleh temuan lain yang lebih baik.

\section{DAFTAR PUSTAKA}

Ahmad, A., Tarmizi, R. A., \& Nawawi, M. (2010). Visual Representations in Mathematical Word Problem Solving among Form Four Students in Malacca. Procedia - Social and Behavioral Sciences, 8(5), 356-361. https://doi.org/10.1016/j.sbspro.2010.12.050

Ainsworth, S., \& VanLabeke, N. (2004). Multiple Forms of Dynamic Representation. Learning and Instruction, 14(3), 241255. https://doi.org/10.1016/j.learninstruc.2004.06.002

Ervin, H. K. (2017). Fraction Multiplication and Division Models: A Practitioner Reference Paper. International Journal of Research in Education and Science, 3(1), 258-279.

Mustafa, U., \& Cuneyt, A. (2016). The Effect of Visuals on Non-Routine Problem Solving Success and Kinds of Errors Made when Using Visuals. Educational Research and Reviews, 11(20), 1871-1888. https://doi.org/10.5897/ERR2016.2980

NCTM. (2000). Principles and Standards for School Mathematics. Reston: The National Council of Teachers of Mathematics, Inc.

Özkan, A., Arikan, E. E., \& Özkan, E. M. (2018). A Study on the Visualization Skills of 6th Grade Students. Universal Journal of Educational Research, 6(2), 354-359. https://doi.org/10.13189/ujer.2018.060219

Stylianou, D. A. (2011). An Examination of Middle School Students' Representation Practices in Mathematical Problem Solving Through the Lens of Expert Work: Towards an Organizing Scheme. Educational Studies in Mathematics, 76(3), 265-280. https://doi.org/https://doi.org/10.1007/s10649-010-9273-2

Van Garderen, D., \& Montague, M. (2003). Visual-Spatial Representation, Mathematical Problem Solving, and Students of Varying Abilities. Learning Disabilities Research and Practice, 18(4), 246-254. https://doi.org/10.1111/15405826.00079 